\title{
L-Metiyoninin Neden Olduğu Nörokognitif Yıkılma: Bir Nörodejenerasyon Fare Modeli
}

\author{
Neurocognitive Decline Caused by L-Methionine: A Mouse Model of \\ Neurodegeneration
}

\author{
Yağız M. Altun ${ }^{1,2}$ (D), Erdem Tüzün' ${ }^{1}$ (D), Mark F. Mehler2,3,4 (D), Şölen Gökhan² (i) \\ IIstanbul Üniversitesi, Aziz Sancar Deneysel Tıp Araştırma Enstitüsü, Sinirbilim Anabilim Dalı, İstanbul, Türkiye \\ ${ }^{2}$ Albert Einstein College of Medicine, The Saul R. Korey Department of Neurology, New York \\ ${ }^{3}$ Albert Einstein College of Medicine, Dominick P. Purpura Department of Neuroscience, New York \\ ${ }^{4}$ Albert Einstein College of Medicine, Department of Psychiatry and Behavioral Sciences, New York
}

ORCID ID:Y.M.A. 0000-0003-0841-6740; E.T. 0000-0002-4483-0394; M.F.M. 0000-0003-0674-7781; S.G. 0000-0002-5939-9074

Cite this article as: Altun YM, Tuzun E, Mehler MF, Gokhan S. L-metiyoninin neden olduğu nörokognitif yıkılma: Bir nörodejenerasyon fare modeli. Experimed 2020; 10(2): 59-66.

\section{ÖZ}

Amaç: Nörodejeneratif hastalıklar geri dönüşü olmayan nöronal ve glial kayıplarla seyreden merkezi sinir sistemi yıkılımıdır. Bu hastalıklar her ne kadar nöral hücre yıkım ortak paydasında birleşseler de her biri farklı klinik bulgularla seyretmektedir. Bu hastalıklarda izlenen klinik tablo spektrumunu inceleyebilmek adına çevresel stresör olarak verilen I-metiyonin yüklemesinin yol açtığı davranış değişikliklerinin ve bu davranış değişikliklerinin temelinde olan immünohistokimyasal değişimlerin incelenmesi amaçlanmıştır.

Gereç ve Yöntem: Bu çalışmada davranış ve immünohistokimya testleri için fareler 4 gruba ayrılmıştır: dişi-kontrol $(n=13)$, dişi-metiyonin $(n=12)$, erkek-kontrol $(n=12)$, erkek-metiyonin $(n=13)$. Kontrol ve deney gruplarına post-natal 6 . haftadan başlayarak, 12 hafta boyunca su veya $8.2 \mathrm{~g} / \mathrm{kg}$ doza ulaşacak şekilde I-metiyoninli su verilmiştir. Bu sürenin sonunda farelere anksiyete, depresyon, hafıza/öğrenme ve motor fonksiyon testleri uygulanmıştır. Davranış testlerinde kullanmadığımız farelerin (her gruptan davranış testleri öncesi rastgele seçilmiş 3 fare) beyin kesitlerinde immünohistokimyasal analizler yapılmıştır.

Bulgular: L-metiyonin alan farelerde almayanlara kıyasla hipokampüs bağımlı mekansal hafızada istatistiksel olarak anlamlı bir fark görülmüştür. Depresyon ve anksiyete adına herhangi bir fark bulunmamıştır. Hipokampüs formasyonunun dentat girusunda yaptığımız immünohistokimyasal incelemede, hem dişi hem de erkek farelerde senesan astrositlerin tüm astrositlere olan oranı arasında istatistiksel olarak anlamlı bir fark saptanmamıştır.

Sonuç: Kronik yüksek doz oral I-metiyonin alımı farelerde anlamlı hipokampüs bağımlı mekansal hafıza bozukluklarına yol açmıştır. Buna paralel olarak, dentat girusta senesan astrositlerin tüm astrositlere oranı da artmıştır.

Anahtar Kelimeler: L-metiyonin, kognitif yıkım, hücresel senesans

\begin{abstract}
Objective: Neurodegenerative diseases are defined by irreversible neuronal and glial loss in the central nervous system. Despite sharing neural cell loss as a common denominator, they differ in their clinical manifestations in many aspects. We aimed to analyze the behavioral changes and underlying immunohistochemical changes in mice caused by an environmental stressor, I-methionine, to assess the spectrum of clinical findings observed in these diseases.
\end{abstract}

Material and Method: In this study, the mice are divided into 4 groups: female-control $(n=13)$, female-methionine $(n=12)$, male-control $(n=12)$, male-methionine $(n=13)$ to perform immunohistochemical and behavioral tests. Starting from post-natal week 6 , the mice were either administered water or $8.2 \mathrm{~g} / \mathrm{kg} \mathrm{l-me-}$ thionine for 12 weeks. Consequently, they underwent a series of behavioral tests to assess anxiety, depression, memory/learning, and motor functions. We performed immunohistochemical analysis on mice (3 randomly chosen mice from each group prior to behavior tests) which did not undergo behavioral tests.

Results: Compared to the control group, mice who received I-methionine were found to have significant hippocampus dependent spatial memory deficits. No significant differences were found in regards to anxiety and depression. Our immunohistochemical analysis showed a significantly increased senescent astrocyte to all astrocyte ratio in dentate gyrus of hippocampal formation.

Conclusion: Chronic administration of an oral high dose of I-methionine results in hippocampus dependent memory decline in mice. Parallel to this finding, the ratio of senescent astrocytes to all astrocytes increased in dentate gyrus.

Keywords: L-methionine, cognitive decline, cellular senescence 


\section{GíRiş}

Nörodejeneratif hastalıklar geri dönüşü olmayan nöronal ve glial kayıplarla seyreden merkezi ve periferik sinir sistemi yıkımıdır. Nörodejeneratif hastalıkların her biri çok farklı klinik tablolarla kendini göstermektedir. Örneğin, Alzheimer hastalığı $(\mathrm{AH})$ hafıza bozukluğu ve diğer kognitif bozukluklarla seyrederken, Parkinson hastalığı (PH) öncelikle motor bozukluklara yol açmaktadır. Süreç içerisinde kognitif bozukluklar da tabloya eklenebilmektedir (1). Hastalık başlangıcı ve seyirleri genetik ve epigenetik farklılıklara ve çevresel stresörlere bağlı olarak değişmektedir. Genel anlamda nörodejeneratif hastalıkların prevalansı insanların ortalama yaşam beklentisinin uzamasıyla artmaktadır. Yapılan çalışmaların büyük bir çoğunluğu nörodejeneratif hastalıkları yaşlanmayla bağdaştırsa da, sayıları giderek artan yeni araştırmalar, bu hastalıkların temelinde sinir sisteminin gelişimsel bozukluklarının yattığını da öne sürmektedir (2). Bu açıdan bakıldığında nörodejeneratif hastalıkların patolojisi hala tam olarak aydınlatılamamıştır.

Nörodejeneratif süreçlerde hastalığın hedefini oluşturan hücrelerin sitoiskeletinde parçalanma, alt bölmelerinde sitoplazmik organellerin balonlaşması, yıkılması (mitokondriyal balonlaşma, genişlemiş lizozomal vaküoller), nörodejeneratif hastalıklara özgü inklüzyon cisimciklerinin belirmesi, (TDP-43 proteinini içeren (3) ve Lewy inklüzyon cisimcikleri vb.), sitoplazma ve nukleoplazmada işlenememiş artıkların çoğalması ve membranların bütünlüğünün bozulmasıyla seyreden çok çeşitli değişiklikler görülür. Buna paralel olarak hücre nöron ve glial bağlantılarında kesiklikler, nöronlar arası sinapslarda yıkılma ve hücreler arası matriks materyelinde de yine işlenememiş artıkların (amiloid, nörofibriler yumak) çoğaldığı görülür (4). Bu sayılan hücre içi ve dışı değişiklikler süreç içerisinde hücre ölümü ile sonuçlanmaktadır. Her ne kadar nöronlar merkezi sinir sisteminin yapı taşları olsalar da, astrositler ve oligodendrositlerde de dejeneratif değişiklikler görülmektedir. Ayrıca astrositler ve sinir sisteminde yer alan diğer bir hücre grubunu oluşturan mikroglialar, inflamatuvar yanıt oluşturarak nörodejenerasyonu hızlandırmaktadır (5).

Nörodejeneratif hastalıklar etkiledikleri bölgelere göre nöroanatomik farklılıklar göstermektedir (6). Kolinerjik nöronların birincil hedef olduğu gösterilmiş $\mathrm{AH}$ 'de bütün kolinerjik nöronlar etkilenmemektedir. Öncelikle Meynert'in bazal nukleusundaki büyük kolinerjik projeksiyon nöronları dejenerasyona uğramaktadır. Bazal nukleustaki bu kolinerjik nöronların fonksiyonlarının bozulmasıyla birlikte bu nöronların uzantılarıyla sinaps yapan kortikal ve hipokampal nöronların fonksiyonlarının değiştiği de gösterilmiştir (7). Hastalığın çok ileri safhalarında hücresel yıkım merkezi sinir sisteminin diğer alanlarına da yayılmaktadır. PH'de ise öncelikli hedef substantia nigra pars kompaktadaki dopaminerjik nöronlardır (8). Benzer bir şekilde Huntington hastalığında hücre dejenerasyonu ve ölümleri öncelikle striatumdaki dopaminerjik orta spinal nöronlarda izlenmektedir (9). Spinoserebellar atakside ise öncelikli yıkım Purkinje hücrelerini etkiler (10). İlginç bir şekilde bunca farklı nörodejeneratif hastalıkta neden bu özel bölgelerin ve hücre gruplarının hedef seçildiği henüz açıklanamamıştır $(11,12)$.
Nörodejeneratif hastalıkların en önemli özelliklerinden biri de klinik bulguların ortaya çıkmasından önce hücreleri etkileyen patolojik değişikliklerin dekatlar boyu sessiz bir şekilde ilerlemeleridir. Kognitif ve diğer nörolojik fonksiyonların klinik tabIonun ortaya çıktığı döneme kadar nasıl olup da korunabildiği henüz aydınlatılamamıştır. Bu konuda bir çok hipotez ortaya atılmış olsa da çevresel etmenlerin, klinik öncesi latent dönemin uzunluğunu belirlediği düşünülmektedir (13). Bu yüzden klinik öncesi dönemde sinir sisteminde süre giden fizyopatolojik değişikliklerin tanısının konulmasını sağlayacak biyomarkerların ve psikometrik testlerin bulunması çok önem kazanmıştır. Böylece ön tanısı konacak hastaların çevresel zararlı etmenlerden kendilerini koruyabilmeleri ve hastalığın klinik tablosunun ortaya çıkmasının mümkün olduğunca geciktirilmesi hedeflenmektedir. Örneğin otozomal dominant bir hastalık olarak bilinen Huntington hastalığına yakalanacağı belirlenen kişilerin, hastalık tablosunun başlamasından 20-30 yıl öncesinde kontrol grubundakilere göre anlamlı derecede artmış konuşma bozuklukları (parafazi) sergilediği gösterilmiştir (14).

Nörodejeneratif hastalıkların etiyopatogenezleri genetik, epigenetik ve çevresel pek çok faktörün etkileşimiyle açıklanmaktadır. Yukarıda saydığımız klasik ailevi nörodejeneratif hastalıkların yanı sıra beslenme (B12 eksikliği) (15), metabolizma bozukluklarına (hipotiroidizm, Wilson hastalığı, glikojen depo hastalıkları vb.) ve çeşitli çevresel toksinlerin (kurşun ve arsenik zehirlenmesi vb.) etkisine bağlı sinir sistemiyle sınırlı olmayan birçok dejeneratif hastalık daha tanımlanmıştır. Son olarak bu çok zengin klinik ve patolojik tabloya genetik ve çevresel faktörlerin nasıl etkili olduğu tam olarak henüz açıklanamayan multipl skleroz hastalığı da eklenmelidir.

Bu hastalıkların çoğu teşhis konulduğunda tedavi edilemeyecek kadar ileri bir klinik tabloya ulaşmış olmaktadırlar. Bununla birlikte B12 eksikliğinin neden olduğu subakut kombine dejenerasyon, yine hem B12 hem de erişkin hipotiroidizminin neden olduğu geçici demansiyel tabloların, bu besinsel ve endokrin eksikliğin telafi edilmesiyle tedavi edilebiliyor olması nörodejeneratif süreçlerin mutlak geri dönüşümsüz olmadığı umudunu vermektedir. Bu yüzden sayıları giderek artan temel bilim ve klinik araştırmalar ortalama insan ömrünün artmasıyla çağımızın en büyük hastalıkları haline gelen nörodejeneratif tabloların erken teşhisi ve tedavisine odaklanmıştır.

Yukarıda saydığımız çevresel faktörler dışında B12 eksikliğine de neden olabilen yüksek I-metiyonin alımının hiperhomosisteinemiye yol açarak (16) nörodejenerasyona neden olabileceği gösterilmiştir (17). Bu tablo genetik mutasyon sonucu sistatiyonin beta sentaz enziminin çalışamadığı durumlarda ortaya çıkmakla birlikte, homosistein siklusunun ön maddesi olan metiyonin amino asitinin aşırı yüklemesiyle de ortaya çıkabilmektedir (Sekil 1). Alınan metiyonini metabolize etmeye yetişemeyen homosistein siklusu vücutta yan ürün olarak homosistein artışına neden olmaktadır. Bu durum görece folik asit, B12 veya B6 vitamini eksikliği yaratıp çeşitli hematolojik (18), nörodejeneratif tablolara (17) ve hatta inmelere (19) yol açmaktadır (20). Hiperhomosisteinemi ayrıca damar cidarında 
endotelyal hücrelerin membran bütünlüğünü bozup, yaygın oksidatif stresle (21) birçok homeostatik mekanizmanın bozulmasına neden olduğunu açıklayan çalışmalar da vardır $(17,22)$. Biz bu çalışmamızda öncelikle homosistein metabolizmasının dekompansasyonuyla ortaya çıktığı gösterilen nörodejeneratif tabloyu hazırlayan (17) ve sonucunda nöroanatomik alanları ve buralardaki hücre tiplerini selektif olarak etkileyebilecek hücre yıkılım sürecini incelemek istedik. Özellikle bu değişikliklerin, nörodejeneratif süreçlerin başlamasında rolü olabileceği yakın zaman önce öne sürülmüş senesans savunma mekanizmasıyla olan ilgisini araştırdık. Bu özel moleküler savunma yolağı öncelikle hücrenin kanserleşmeye karşı geliştirdiği bir direnç mekanizması olarak tanımlanmıştır. İmmünohistokimyasal çalışmalarda, senesans mekanizmasına giren hücreler, özel senesansla alakalı beta-galaktozidaz (SA $\beta$-Gal) boyamasıyla belirlenmiştir. Bu hücrelerde SA $\beta$-Gal boyası, kanserleşmeyi tetikleyen çevresel strese bağlı olarak aktive olan lizozomlarda $\beta$-galaktozidaz enziminin arttığını göstermektedir (23). Ancak bu artış sonucunda tetiklenen kanser, hücre ölümü ve nörodejeneratif süreçleri başlatan moleküler yolaklardaki değişikliklerin incelenmesi hala devam etmektedir. Özellikle senesansın hedef hücrede nörodejenerasyonu başlatan mı, yoksa ona karşı oluşan moleküler bir savunma mekanizması mı olduğu bilinmemektedir. Bu amaçla çalışmamızda, daha önce nörodejenerasyona neden olduğu gösterilmiş çevresel bir faktörü (organ yetmezliği dozu altı I-metiyonin yüklemesi) kullanarak akut dönemde farelerde gelişebilecek bilişsel, duygudurum, motor ve denge bozuklukları ve bu sürecin altında yatabilecek hücresel değiş̧iklikler çeşitli davranış testleri ve immünohistokimyasal yöntemlerle analiz edilmiştir.

\section{GEREÇ VE YÖNTEM}

Kontrol ve Deney Grubu Fareler ve L-metiyonin Yüklemesi T.C. İstanbul Üniversitesi Rektörlüğü Hayvan Deneyleri Yerel Etik Kurulu Başkanlığı́nın 2018/07 nolu etik kurul onayınca hayvan deneyleri yürütülmüştür. Deneylerimizde hem dişi hem de erkek C57BL6 fareler kullanılmıştır. Deney ve kontrol grubu fareleri, doğumdan itibaren 6 hafta boyunca kontrollü bir ortamda tutulmuş ve hiçbir dış değişkene maruz kalmamışlardır. Diyetleri normal devam etmiştir. İlk 4 hafta boyunca anne fare tarafından emzirilmişlerdir. 4. haftanın sonunda cinsiyetlerine göre ayrılmış ve her kafeste 5 fare olacak şekilde gelişimlerini tamamlamışlardır. Daha önce Tapia-Rojas ve ark. (17) tarafından standardize edildiği üzere, 12 hafta boyunca içme suyu aracılığıyla I-metiyonin (doz: $8.2 \mathrm{~g} / \mathrm{kg}$ ) almışlardır. Bu süre zarfında farelerin su veya I-metiyonin tüketimleri ve kilo değişimleri takip edilmiştir. Veteriner hekim takibinde herhangi bir klinik düşkünlük tablosu gözlenmemiştir.

\section{Kas-İskelet Bozukluğu Testi}

Açık Alan Testi: Her ne kadar standardize edilmiş davranış testleriyle bilişsel ve duygudurum bozukluklarını ölçüyor olsak da, bu bozukluğun altta yatan temeli bazen inme veya merkezi sinir sistemi (MSS) tümörü vb. fokal strüktürel bozukluklar olabilmektedir. Bu tarz hastalıklar bilişsel bozukluğun yanı sıra pek çok diğer nörolojik bozukluğa neden olup testlerin sonuçlarını olumsuz yönde etkileyebilmektedir. Ayrıca çeşitli kas-iskelet bozuklukları da MSS motor fonksiyon testlerinde yanlış pozitiflik ortaya çıkarabilmektedir. Bu durum daha sonraki testleri yanlış yönlendirebilmektedir. Bu amaçla açık alan testi ile be-

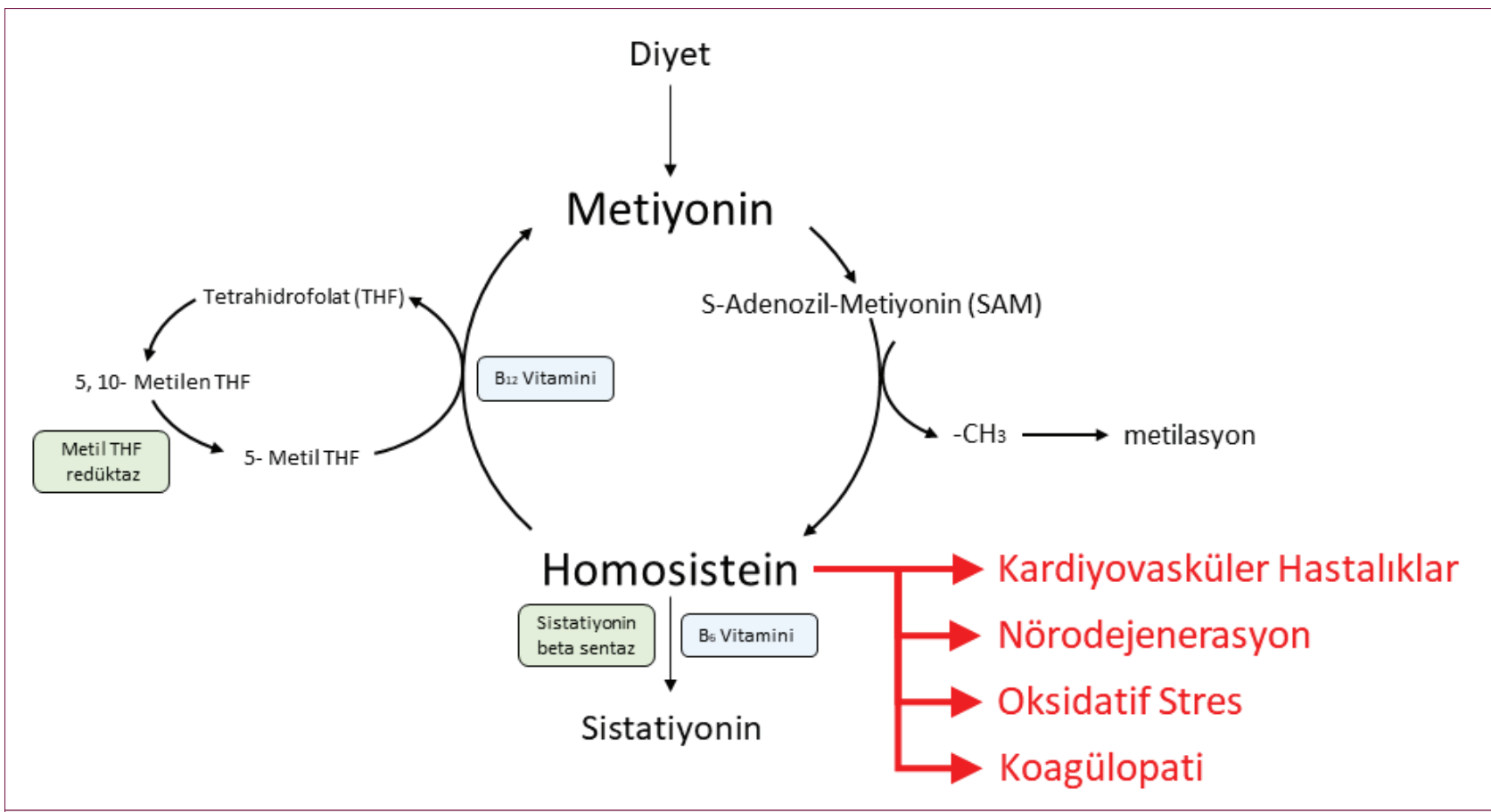

Şekil 1. Metiyonin/homosistein siklusu. https://www.inner-alchemy.com.au/inner-alchemy-blog/2017/10/22/mthfr-10-tipsto-supporting-mthfr internet sayfasından alınarak modifiye edilmiştir. 
lirgin bozukluğu olan fareleri deney ve kontrol gruplarından çıkarmak amaçlanmıştır. Bu test ile fareler $40 \mathrm{~cm}$ x $40 \mathrm{~cm}$ lik yukarıdan aydınlatılmış üstü açık kutuya konularak belirgin bir lokal motor bozukluğun olup olmadığı incelenmiştir.

\section{Anksiyete Testi}

Yükseltilmiş Artı Labirent Testi (YALT): Farelerde anksiyete düzeyini ölçmeye yarayan testlerden biridir. YALT yerden bir metre yükseltilerek "+" şeklinde tasarlanmış bir platformdur. Bu artının iki kolu kapalı ve diğer iki kolu ise açıktır. Test süresince farenin açık ya da kapalı kollarda ne kadar hareket ettiği ve ne kadar süre kaldığı kamera ile kaydedildikten sonra ANY-Maze yazılımı aracılığı ile değerlendirilmektedir. Kapalı kollarda geçirilen zamanın öncelikli artışı anksiyeteye işaret etmektedir.

\section{Depresyon Testi}

Zorunlu Yüzme Testi: Depresyon benzeri davranışı ölçmek için Porsolt'un zorunlu yüzme testi kullanılmıştır. Bu testte 4 L'lik beher kaplarına oda sıcaklığında su konulduktan sonra fareler tek tek suya bırakılır ve 10 dakika boyunca farelerin sudaki hareketli ve hareketsiz kalma süreleri izlenir. Farelerin su yüzeyinde hareketsiz kalmayı tercih etmesi depresyona işaret etmektedir.

\section{Hafıza ve Öğrenme Testleri}

Nesne-mekan testi: Farelerin yalnızca hipokampüse bağımlı hafızalarını test etmek için nesne tanıma testi kullanılmıştır. Bu test için iki adet aynı nesne (kemirgenler için ilgi çekici) test kutusu içinde farklı yerlere yerleştirilir. Farelerin nesnelerin yerlerini hatırlayabilmeleri için davranış testi alanının duvarlarına görsel ipuçları eklenir. Böylelikle fareler uzaysal olarak her iki objeyi 4 dakika boyunca inceleyebilmektedir. Daha sonra nesnelerden biri farklı bir konuma yerleştirilir ve farenin bu değişiklikten sonra her iki nesneyi izlediği süreler not edilir. Öğrenim ve test arasındaki süre testten teste değişebilmektedir. Bu yüzden standart olarak bu testler 40 ya da 70 dakikalık aralıklarla yapılır. Farenin ilgisi dağıldığından daha uzun süre verilmemektedir. Çalışmamızda testlerimiz için 70 dakikalık süre uygulanmıştır.

Nesne Tanıma Testi: Farelerin hipokampüsten bağımsız hafızalarını test etmek için nesne tanıma testi kullanılmıştır. Yapılan araştırmalara göre bu test hipokampüs ve kortikal nöronal sinir ağlarının ortak katılımını gerektirmektedir (24). Bu test için birbirine tıpatıp benzeyen iki objeyi incelemeleri için fareler $40 \mathrm{~cm}$ x 40 cm'lik davranış alanına yerleştirilmiştir. Test alanında herhangi başka bir görsel ipucu olmamasına özen gösterilmiştir. Daha sonra fareler bu iki nesneyi incelemek için 10 dakika test alanında bırakılmıştır. İnceleme sonrasında fareler kafeslerine konup hayvan odasına geri götürülmüşlerdir. Bir gün sonra, aynı test alanında nesnelerden bir tanesini değiştirip farelerin verdiği tepki ANY-Maze Behavioral Tracking Software ile kaydedilmiş ve incelenmiştir.

\section{Motor Fonksiyon Testi}

Denge Kirişi Testi: Denge kiriş testi için $1 \mathrm{~cm}$ kalınlığında ve 1 metre uzunluğunda pleksiglastan yapılmış bir kiriş yerden 1 metre yükseklikte iki tahta ayak üzerine sabitlenmiştir. Farelerin ilk iki gün günde üç defa olmak üzere denge kirişinde yürütüle- rek ortama alışmaları sağlanmıştır. Sonraki iki gün yine günde üç deneme yaparak farelerin denge kirişindeki yürürken ön ya da arka ayaklarının kayma sayısı takip edilmiştir. Toplamda elde edilen kayma (denge kaybı) sayıları istatistiksel olarak incelenmiştir.

\section{3,3'-Diaminobenzidine Boyaması}

3,3'- Diaminobenzidine (DAB) boyaması için ise dokular endojen peroksidaz enzimi aktivitesini bertaraf etmek için öncelikle 10 dakikalık $\mathrm{H}_{2} \mathrm{O}_{2}$ solüsyonuna tabi tutuldu. Daha sonra uygun hayvan serumu ile sabitlenen beyin kesitleri uygun antikorlarla işaretlendi. Akabinde ikincil biyotinlenmiş antikorlar, DAB kokteyli ve $A B C$ kiti solüsyonlarıyla kesit mikroskopik incelemeye hazır hale getirildi.

\section{Senesansla Alakalı $\boldsymbol{\beta}$-Galaktozidaz Boyaması}

SA $\beta$-Gal yukarıda belirtilen immünolojik boyamaya ek olarak yapılan ve senesans savunma mekanizmasını oluşturmuş hücrelerin ek olarak boyanmasını sağlayan bir metottur. Buna göre daha önceki reaksiyonlara ek olarak, dokular CBA-230 Cellular Senescence Assay Kit solüsyonları ile fikse edildi ve ek olarak $\mathrm{X}$-Gal solüsyonu ile birlikte $+37^{\circ} \mathrm{C}$ 'de 24 saat inkübe edildi.

\section{İstatistiksel Analiz}

Davranış testlerindeki değişimler istatistiksel olarak ki-kare testi, iki yönlü ANOVA ve post-hoc analiz olarak Tukey'in çoklu karşılaştırması kullanılarak hesaplandı ve $p<0.05$ değeri anlamlı kabul edildi. Grafiklerde su ve metiyonin alanlar arasındaki istatistiksel anlamlılık* (asterisk) ile, metiyonin alan erkek ve dişi fareler arasındaki istatistiksel anlamlı farklılık is $\Delta$ (delta) ile gösterildi $(p \leq 0.05$ için *; $p \leq 0.01$ için **; $p \leq 0.001$ için ***; $p \leq 0.0001$ için **** sembolleri kullanıldı). İstatistiksel analiz için Graphpad Prism 8.4.3 programı kullanıldı.

\section{BULGULAR}

\section{Kontrol ve Deney Grubu Farelerinin Klinik Açıdan Karşılaştırılması \\ Davranış testleri başlamadan önce farelerin herhangi bariz kli- nik nörolojik defisitlerinin olmadığı açık alan testi ile teyit edil- miştir. Deneylerimizde tüm fareler birbirine benzer davranışlar sergilediğinden hiçbir fare deney dışında bırakılmamıştır.}

\section{Kontrol ve Deney Grubu Farelerinin Anksiyete Düzeyleri Açısından Karşılaştırılması}

L-metiyonin alımının hemen ardından yapılan yükseltilmiş labirent testinin sonuçları iki yönlü ANOVA ile analiz edildiğinde I-metiyonin alan ve almayan dişi ve erkek grupları arasında anlamlı bir istatistiksel farklılık gözlenmemiştir $\left(F_{(1,35)}=0.2778\right.$; $p=0.6015$ ) (Şekil 2-A).

\section{Kontrol ve Deney Grubu Farelerinin Depresyon Düzeyleri Açısından Karşılaştırılması}

Farelerin yüzme davranışlarına göre depresyon paternlerini inceledik. Zorunlu yüzme testinin sonuçları iki yönlü ANOVA ile analiz edildiğinde I-metiyonin alan ve almayan dişi ve erkek grupları arasında anlamlı bir istatistiksel farklılık gözlenmemiş$\operatorname{tir}\left(F_{(1,15)}=1.317 ; p=0.2690\right)$ (Şekil 2-B). 


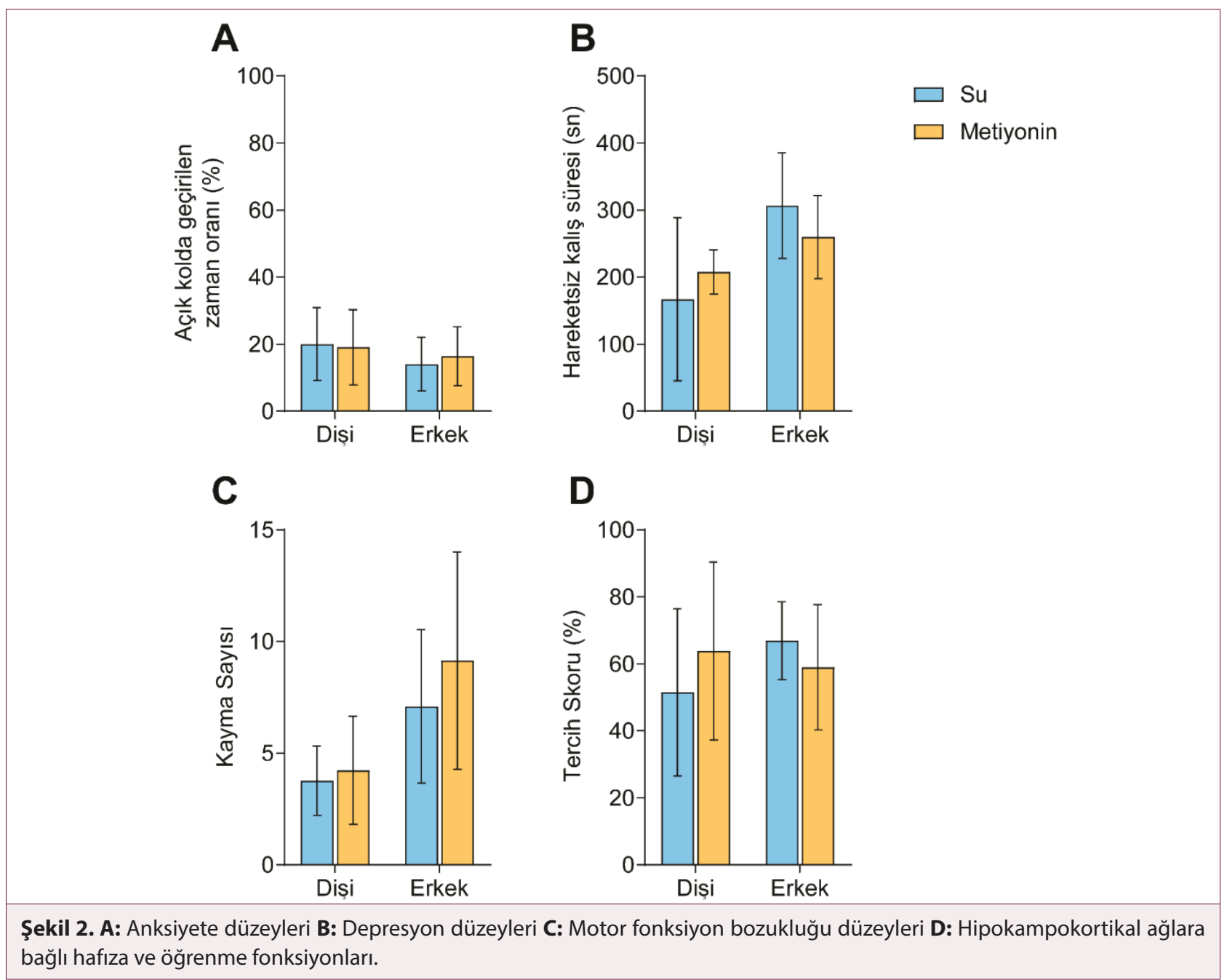

Kontrol ve Deney Grubu Farelerinin Motor Fonksiyonları Açısından Karşılaştırılması

Denge kirişi testinin sonuçları iki yönlü ANOVA ile analiz edildiğinde I-metiyonin alan ve almayan dişi ve erkek grupları arasında anlamlı bir istatistiksel bir farklılık gözlenmemiştir $\left(F_{(1,}\right.$ $25)=0.3036 ; p=0.5865$ ) (Şekil 2-C).

Kontrol ve Deney Grubu Farelerinin Hipokampokortikal Ağlara Bağlı Hafıza ve Öğrenme Fonksiyonları Açısından Karşılaştırılması

Bu test ile farelerin bir gün arayla yeni objeyi tanıyarak onu inceleme isteğini analiz ettik. Bu test ile yalnızca hipokampüse değil hafızanın işlenmesine katılan diğer kortikal yapıları da (entorinal, peririnal korteks ve parahipokampal bölge) test etmiş olduk. Nesne tanıma testinin sonuçları iki yönlü ANOVA ile analiz edildiğinde I-metiyonin alan ve almayan dişi ve erkek grupları arasında anlamlı bir istatistiksel bir farklılık gözlenme$\operatorname{miştir}\left(F_{(1,34)}=2.147 ; p=0.1521\right)$ (Şekil 2-D).

Kontrol ve Deney grubu farelerinin hipokampüse bağlı mekansal hafıza fonksiyonları açısından karşılaştırılması

Nesne-mekan testinin sonuçları dişiler ve erkekler olarak ayrı ayrı ki-kare testine tabi tutulmuştur. Dişilerin su alanları ile I-metiyonin alanları arasında anlamlı bir fark görülmektedir. $(x 2(1)=24.72 ; p<0.0001)$ Buna ek olarak su alan erkek fareler ile I-metiyonin alan erkek fareler arasında da anlamlı bir istatistiksel fark görülmektedir ( $x 2(1)=13.79 ; p=0.0002)$ (Şekil 3).

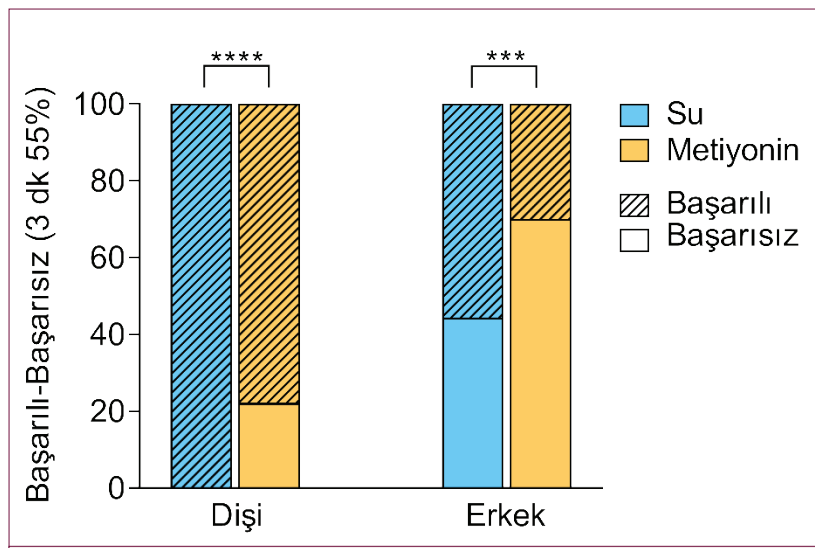

Şekil 3. Hipokampüse bağlı mekansal hafıza fonksiyonları. 


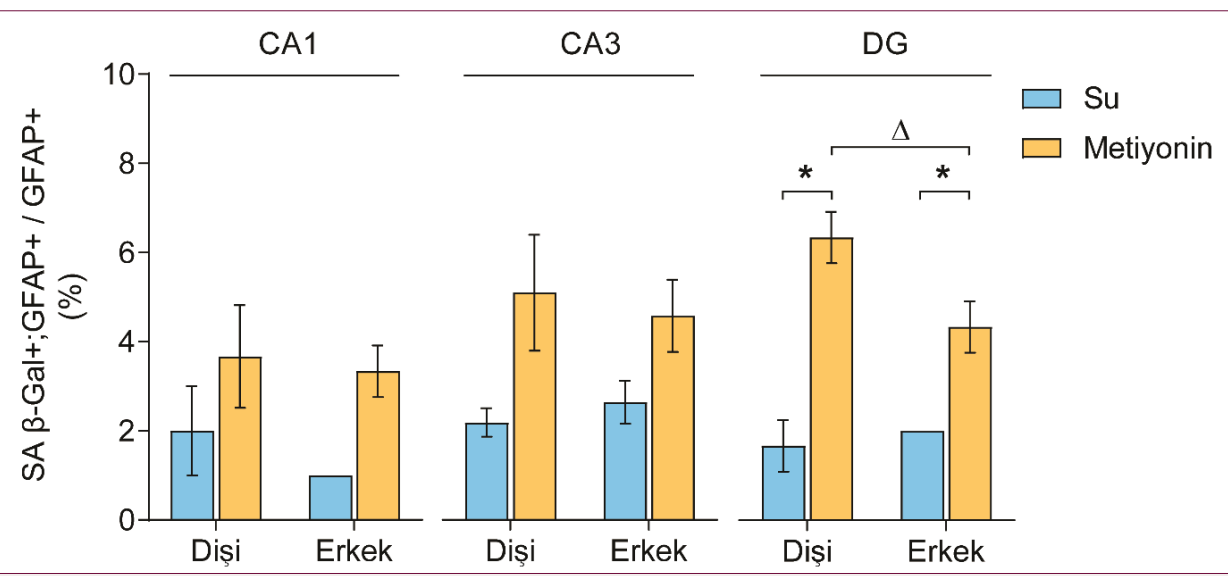

Şekil 4. CA1, CA3 ve dentat girusta (DG) senesan astrositlerin tüm astrositlere oranı.

\section{Hipokampal Bölgelerde Senesan Hücre Oranlarındaki Değişikliklerin Karşılaştırılması}

Yaptığımız immünohistokimyasal ön taramalar, hipokampüste nöron, mikroglia ve oligodendrositlerin yoğunluğunda ve bu hücrelerin senesan olanlarının yoğunluğunda belirgin bir değişiklik göstermemiştir (veriler gosterilmedi). Her üç alanda (dentat girus, CA1, CA3) senesan astrositlerin tüm astrositlere olan oranını incelediğimizde, bu oranın I-metiyonin alan dişi ve erkek farelerin su alanlara kıyasla trend olarak daha yüksek olduğu gözlemlenmiştir (Şekil 4). CA1'de senesan astrositlerin tüm astrositlere oranını cinsiyet ve I-metiyonin iki değişkenine bağlı olarak iki yönlü ANOVA testi incelediğimizde anlamlı istatistiksel fark saptanmamıştır $\left(F_{(1,8)}=0.5000 ; p=0.4996\right)$. Bu oranı CA3'te yine aynı değişkenler açısından iki yönlü ANOVA testi ile incelediğimizde yine istatistiksel olarak anlamlı bir fark görülmemiştir $\left(F_{(1,8)}=1.071 ; p=0.3309\right)$. Son olarak dentat girusta, senesan astrositlerin tüm astrositlere oranı adına I-metiyonin alma ve cinsiyet değişkenleri dahilinde iki yönlü ANOVA testinde istatistiksel olarak anlamlı bir fark görülmektedir $\left(F_{(1}\right.$, $\left.\left.{ }_{8}\right)=16.33 ; p=0.0037\right)$. Akabinde yaptığımız Tukey çoklu analizinde, su alan ( $n=3,1.667 \pm 0.5774,95 \% \mathrm{Cl}[0.234,3.101])$ ve I-metiyonin alan $(n=3,6.333 \pm 0.5774,95 \% \mathrm{Cl}[4.899,7.768])$ dişi fareler arasında $(p<0.0001)$, su alan $(n=3,2.000 \pm 0,95 \% \mathrm{Cl}[2.000$, $2.000])$ ve I-metiyonin alan $(n=3,4.333 \pm 0.5774,95 \% \mathrm{Cl}[2.899$, 5.768]) erkek fareler arasında ( $p=0.0037)$ ve son olarak I-metiyonin alan dişi $(n=3,6.333 \pm 0.5774,95 \% \mathrm{Cl}[4.899,7.768])$ ve erkek fareler $(n=3,4.333 \pm 0.5774,95 \% \mathrm{Cl}[2.899,5.768])$ arasında istatistiksel olarak anlamlı ( $p=0.0052$ ) farklılıklar saptanmıştır. Bu ön çalışma sonucunda MSS'deki diğer hücrelerden farklı olarak astrositlerde senesans yolağının öncelikli olarak aktive edildiğini düşünmekteyiz. Bu hücresel değişikliğin akut bir reaksiyon mu, yoksa uzun dönemde nörodejenerasyon ve hücre kaybıyla sonlanacak kronik bir sürecin başlangıcı mı olduğu sorusuna cevaplar daha sonraki çalışmalarımızda incelenecektir.

\section{TARTIŞMA}

Hiperhomosisteinemi kemirgen modelleri uzun yıllardır çok farklı hastalıkların etiyopatogenezinin araştırılması için kullanılmaktadır $(25,26)$. Kardiyovasküler, nörodejeneratif hastalıklardan retinal inflamasyona kadar birçok patolojinin araştırılmasında hiperhomosisteinemi modelleri kullanılmıştır $(27,28)$. Hiperhomosisteineminin nörodejenerasyondaki rolünün, vasküler yapıya olan direk hasardan mı, neden olduğu oksidatif stresten mi, yoksa bunların kombinasyonunun tetiklediği başka moleküler yolakların işlev değiştirmesinden dolayı mı olduğu henüz tam anlamıyla netleştirilememiştir (29). Homosistein, bulunduğu ortamda sahip olduğu sülfür bağı nedeniyle çevresindeki moleküllerle artmış elektron alışverişinde bulunarak Red/Ox dengesini bozmaktadır (30). Bu durum bu aminoasitin çok farklı patofizyolojik yolaklarda etkili olmasına neden olmaktadır (31).

Çalışmamızda her ne kadar biyokimyasal testlerle dinamik plazma homosistein konsantrasyonunu incelememiş olsak da, daha önce yüksek doz l-metiyoninin alımının hiperhomosisteinemiye yol açtığını kanıtlayan bir çalışmadan (32) daha yüksek bir doz kullanılmıştır. Kronik I-metiyonin yüklemesine tabi tutulmuş farelerde hiperhomosisteinemi modeli oluşturmaya çalışılmış ve bu negatif etkinin beyinde hangi hücre gruplarını etkilediği araştırılmıştır. L-metiyonin alıp almamalarına ve cinsiyetlerine göre karşılaştırılabilir gruplara ayrılmış fareler, standardize edilmiş çeşitli davranış testleriyle incelenmiştir. Bu çalışmalarda seçilen I-metiyonin yükleme dozunun organ yetmezliğine neden olabilecek eşiğin altında olmasına dikkat edilmiştir. (33). Bu yükleme sonucunda beklemediğimiz bir şekilde hem dişi hem de erkek farelerde sadece hipokampüse bağlı mekansal hafızaya bağlı bir bozulma olduğu gözlenmiştir. Ayrıca erkek farelerin dişilere kıyasla nesne-mekan testinde istatistiki olarak anlamlı olmasa da farklılık gösterdiği saptanmıştır $(17,34)$ (Şekil 2-C). Bu farklılık bize, dişi ve erkek fare cinslerinin I-metiyonin yüklemesine karşı değişik dirence sahip olduğunu düşündürmüştür. Cinsiyet farklılığının davranış paternleri üzerine etkisi ile ilgili bir çok yayın yapılmış olmasına rağmen (35), bu farklılığın alt yapısını oluşturan nöroanatomik alanların cinsiyete göre işlevselliği ve stresör hassasiyetleri henüz tam anlamıyla anlaşılamamıştır.

Daha önce yapılan çalışmalarda hafıza fonksiyonlarının teste tabi tutulan öznenin duygu durumundan etkilenebileceği gösterilmiştir (36). Bununla birlikte çalışmamızda kullandığımız yüksek doz I-metiyonin uygulanmış fare modelinde ne dişi, 
ne de erkek farelerde anksiyete ve depresyon görülmemiştir.. Böylelikle duygudurum değişikliklerinin hafıza testlerinin sonuçlarını etkileme ihtimali ortadan kalkmaktadır. Bu açıdan bakıldığında kullandığımız modelin salt hafıza bozukluğunu incelemek açısından avantajlı olduğu ortaya çıkmaktadır.

Çalışmamızda nörodejenerasyonun sinir sisteminde etkilediği alanların yaygınlığını incelemek açısından bilişsel ve duygudurum testlerinin yanı sıra motor ve denge testleri de kullanılmıştır. Ne dişi, ne de erkek farelerde herhangi bir motor ya da denge kusuruna rastlanmamıştır. Dolayısıyla yaptığımız çalışmada yüksek doz I-metiyoninin olumsuz etkisine en fazla duyarlı nörolojik alanın hipokampal bölgeler olduğu düşünülmektedir. Bununla birlikte uzun dönemde I-metiyonin yüklemesinin etkileri sinir sisteminde yaygın hasara da neden olabilir. Öte yandan hipokampokortikal devrelere bağlı hafıza üzerinde anlamlı bir farkIılık bulamamış olmamız, ya bu bölgelerin I-metiyonin etkisine daha dirençli olduğunu, ya da bu devreleri oluşturan diğer nöroanatomik alanlarda (striatum, substantia nigra, entorinal korteks vb.) bilişsel işlevleri negatif etkileyebilecek nörodejenerasyonun henüz oluşmadığını düşündürmektedir. Bu söz konusu anatomik ve hücresel değişiklikleri daha sonra yapacağımız çalışmalarda daha derinlemesine araştırmayı planlamaktayız.

Günümüze kadar nörodejenerasyonu açılayan moleküler yolaklar içinde oksidatif stres (37), apoptozis (38), bağırsak disbiyozu $(39,40)$, hücresel senesans (41) vb. pek çok mekanizma öne sürülmüştür. Bu çalışmamız I-metiyonin yüklemesinin akabinde hippokampüste hücre kaybı olmaksızın, hücresel senesans mekanizmasının özellikle astrositlerde artmış olduğunu göstrmektedir. Ancak bu hücresel yanıtın akut bir cevap mı olduğunu, yoksa giderek nörodejenerasyon ve hücre kaybıyla seyredecek bir sürecin başlangıcı mı olduğu konusunda çalışmalarımız devam etmektedir.

Hücresel senesans ilk tanımlandığında çeşitli stresörlere maruz kalan hücrenin kanserleşmeyi önlemek adına geliştirdiği bir savunma yöntemi olarak tanımlanmıştır. Bu teori senesansı, kanserleşme ve apoptozis arasında seçim yapmak durumunda kalan hücrenin, hücre siklusundan çıkıp, apoptotik yolakları geçici olarak inhibe edip on yıllar boyunca temel işlevlerini idame ettirebildiği bir dönem olarak tanımlanmıştır (42). Ancak bu savunma mekanizması hücreyi ilelebet koruyamamaktadır. Senesansa giren hücreler, daha önce de belirttiğimiz gibi immünohistokimyasal yöntemlerle SA $\beta$-Gal boyası ile belirlenir. Ancak son yıllarda yapılan immünohistokimyasal çalışmalar bu SA $\beta$-Gal boyamasının, kanser dışındaki sinir sisteminin embriyonik gelişiminde programlı hücre ölümünden çok çeşitli nörodejeneratif süreçlere varan ortamlarda senesansa girmiş hücrelerin varlığını göstermiştir (43-45). Bu bağlamda embriyonik gelişim ya da nörodejenerasyon sürecinde hücresel senesansın kanserde olduğu gibi genetik, epigenetik ve çevresel stresler tarafından işlevselliği bozulmuş hücrelerin ayıklanmasını tetikleyen bir süreç mi olduğu, yoksa bu özel hücresel konumlarda nörodejenerasyonu engellemek için geliştirilmiş bir savunma mekanizması mı olduğu, ya da tam tersine nörodejenerasyonu başlatan moleküler yolakları aktive mi ettiği bilinmemektedir. Son olarak hücresel senesans, bütün bu fizyolojik gelişimsel ve patolojik süreçlerden bağımsız olarak, moleküler yolaklarda ortaya çıkan epifenomenolojik değişiklikleri de yansıtıyor olabilir. Bu soruları cevaplayabilmek için daha sonraki çalışmalarımızda I-metiyonin yüklemesi yapılmış farelerde uzun dönemde hipokampüste ve hafızayı destekleyen diğer nöroanatomik alanlarda ortaya çıkabilecek immünohistokimyasal ve ultrastrüktürel değişimleri incelemeyi amaçlıyoruz. Böylece hücresel senesans mekanizmasının tek başına nörodejenerasyonu başlatmaya yeterli olup olmadığı konusunda açıklık getirilecektir.

Etik Komite Onayı: İstanbul Üniversitesi Rektörlüğü Hayvan Deneyleri Yerel Etik Kurulu Başkanlığı'nın 2018/07 no'lu etik kurul onayınca hayvan deneyleri yürütülmüştür.

\section{Hakem Değerlendirmesi: Dış bağımsız.}

Yazar Katkıları: Fikir - Y.M.A., E.T., M.F.M., S.G.; Denetleme - Y.M.A., E.T., M.F.M., S.G.; Gereçler - M.F.M., S.G.; Veri Toplanması ve/veya İşlemesi Y.M.A.; Analiz ve/veya Yorum - Y.M.A., S.G.; Literatür Taraması - Y.M.A.; Yazan - M.F.M., S.G.; Eleştirel İnceleme - S.G.

Çıkar Çatışması: Yazarlar çıkar çatışması bildirmemişlerdir.

Finansal Destek: Bu çalışmada bildirilen araştırmalar Ulusal Sağlık Enstitüleri (Amerika Birleşik Devletleri) tarafından desteklenmiştir (Ulusal Nörolojik Bozukluklar ve İnme Enstitüsü - R01NS073758).

Ethics Committee Approval: Animal experiments were conducted after the approval of the Ethics Committee of Istanbul University Rectorate Animal Experiments Local Ethics Committee No: 2018/07.

Peer-review: Externally peer-reviewed.

Author Contributions: Concept - Y.M.A., E.T., M.F.M., S.G.; Supervision - Y.M.A., E.T., M.F.M., S.G.; Materials - M.F.M., S.G.; Data Collection and/or Processing - Y.M.A.; Analysis and/or Interpretation - Y.M.A., S.G.; Literature Search - Y.M.A.; Writing - M.F.M., S.G.; Critical Reviews - S.G.

Conflict of Interest: The authors have no conflict of interest to declare.

Financial Disclosure: Research reported in the present work was supported by the National Institutes of Health (National Institute of Neurological Disorders and Stroke Grant RO1NS073758).

\section{KAYNAKLAR}

1. Kovacs GG. Concepts and classification of neurodegenerative diseases. Handb Clin Neurol 2017; 145: 301-7. [CrossRef]

2. Molero, AE, Gokhan S, Gonzalez S, Feig JL, Alexandre LC, Mehler MF. Impairment of developmental stem cell-mediated striatal neurogenesis and pluripotency genes in a knock-in model of Huntington's disease. Proc Natl Acad Sci U S A 2009; 106: 21900-5. [CrossRef]

3. Hardiman O, Al-Chalabi A, Chio A, Corr EM, Logroscino G, Robberecht W, et al. Amyotrophic lateral sclerosis. Nature Reviews Disease Primers 2017; 3: 17071. [CrossRef]

4. DeTure MA, Dickson DW. The neuropathological diagnosis of Alzheimer's disease. Mol Neurodegener 2019; 14: 32. [CrossRef]

5. Gelders G, Baekelandt V, Van der Perren A. Linking neuroinflammation and neurodegeneration in parkinson's disease. Journal of İmmunology Research 2018; 4784268. [CrossRef] 
6. Braak H, Del Tredici K, Schultz C, Braak E. Vulnerability of select neuronal types to Alzheimer's disease. Ann NY Acad Sci 2000; 924 : 53-61. [CrossRef]

7. Whitehouse PJ, Price DL, Clark AW, Coyle JT, DeLong MR. Alzheimer disease: evidence for selective loss of cholinergic neurons in the nucleus basalis. Ann Neurol 1981; 10: 122-6. [CrossRef]

8. Dickson DW. Parkinson's disease and parkinsonism: neuropathology. Cold Spring Harb Perspect Med 2012; 2. [CrossRef]

9. Sapp E, Schwarz C, Chase K, Bhide PG, Young AB, Penney J, Vonsattel JP, Aronin N, DiFiglia M. Huntingtin localization in brains of normal and Huntington's disease patients. Ann Neurol 1997; 42: 604-12. [CrossRef]

10. Pérez Ortiz JM, Orr HT. Spinocerebellar Ataxia Type 1: Molecular Mechanisms of Neurodegeneration and Preclinical Studies. Adv Exp Med Biol 2018; 1049: 135-45. [CrossRef]

11. Mehler MF, Gokhan S. Mechanisms underlying neural cell death in neurodegenerative diseases: alterations of a developmentally-mediated cellular rheostat. Trends Neurosci 2000; 23: 599-605. [CrossRef]

12. Mehler MF, Gokhan S. Developmental mechanisms in the pathogenesis of neurodegenerative diseases. Prog Neurobiol 2001; 63: 337-63. [CrossRef]

13. Armstrong RA. Risk factors for Alzheimer's disease. Folia Neuropathologica 2019; 57: 87-105. [CrossRef]

14. Illes J. Neurolinguistic features of spontaneous language production dissociate three forms of neurodegenerative disease: Alzheimer's, Huntington's, and Parkinson's. Brain Lang 1989; 37: 628-42. [CrossRef]

15. Brian C, Dalla Torre C, Citton V, Manara R, Pompanin S, Binotto G, et al. Cobalamin deficiency: clinical picture and radiological findings. Nutrients 2013; 5: 4521-39. [CrossRef]

16. Hrnčić $D$, Rašić-Marković $A$, Stojković $T$, Velimirović $M$, Puškaš $N$, Obrenović R et al. Hyperhomocysteinemia induced by methionine dietary nutritional overload modulates acetylcholinesterase activity in the rat brain. Mol Cell Biochem 2014; 396: 99-105. [CrossRef]

17. Tapia-Rojas C, Lindsay CB, Montecinos-Oliva C, Arrazola MS, Retamales RM, Bunout $D$ et al. Is L-methionine a trigger factor for Alzheimer's-like neurodegeneration?: Changes in $A \beta$ oligomers, tau phosphorylation, synaptic proteins, Wnt signaling and behavioral impairment in wild-type mice. Molecular neurodegeneration 2015; 10: 62. [CrossRef]

18. Durand P, Prost M, Loreau N, Lussier-Cacan S, Blache D. Impaired Homocysteine Metabolism and Atherothrombotic Disease. Laboratory Investigation 2001; 81: 645-72. [CrossRef]

19. Bath PM, Appleton JP, Sprigg N, The Insulin Resistance Intervention after Stroke trial: A perspective on future practice and research. International Journal of Stroke 2016; 11: 741-43. [CrossRef]

20. Yoshitomi R, Nakayama K, Yamashita S, Kumazoe M, Lin T-A, Mei $\mathrm{C}-\mathrm{Y}$ et al. Plasma Homocysteine Concentration is Associated with the Expression Level of Folate Receptor 3. Scientific reports 2020; 10: 10283. [CrossRef]

21. Schöneich $C$. Methionine oxidation by reactive oxygen species: reaction mechanisms and relevance to Alzheimer's disease. Biochim Biophys Acta 2005; 1703: 111-9. [CrossRef]

22. LiY, Huang T, Zheng Y, Muka T, Troup J, Hu FB. Folic Acid Supplementation and the Risk of Cardiovascular Diseases: A Meta-Analysis of Randomized Controlled Trials. J Am Heart Assoc 2016; 5. [CrossRef]

23. Debacq-Chainiaux F, Erusalimsky JD, Campisi J, Toussaint O. Protocols to detect senescence-associated beta-galactosidase (SA$\beta$ gal) activity, a biomarker of senescent cells in culture and in vivo. Nature Protocols 2009; 4: 1798-806. [CrossRef]

24. Tomé WA, Gökhan Ş, Brodin NP, Gulinello ME, Heard J, Mehler MF, et al. A mouse model replicating hippocampal sparing cranial irradiation in humans: A tool for identifying new strategies to limit neurocognitive decline. Sci Rep 2015; 5: 14384. [CrossRef]
25. Quéré I, Hillaire-Buys D, Brunschwig C, Chapal J, Janbon C, Blayac $J P$, et al. Effects of homocysteine on acetylcholine- and adenosine-induced vasodilatation of pancreatic vascular bed in rats. British journal of pharmacology 1997; 122: 351-7. [CrossRef]

26. Montalescot G. Homocysteine: the new player in the field of coronary risk. Heart (British Cardiac Society) 1996; 76: 101-2. [CrossRef]

27. Elsherbiny NM, Sharma I, Kira D, Alhusban S, Samra YA, Jadeja R et al. Homocysteine Induces Inflammation in Retina and Brain. Biomolecules 2020; 10: 393. [CrossRef]

28. McCully KS, Vascular pathology of homocysteinemia: implications for the pathogenesis of arteriosclerosis. The American journal of pathology 1969; 56: 111-28.

29. Bellamy MF, McDowell IFW. Putative mechanisms for vascular damage by homocysteine. Journal of Inherited Metabolic Disease 1997; 20: 307-15. [CrossRef]

30. Chen S, Wu P, Zhou L, Shen Y, Li Y, Song H. Relationship between increase of serum homocysteine caused by smoking and oxidative damage in elderly patients with cardiovascular disease. International journal of clinical and experimental medicine 2015; 8: 4446-54.

31. Sikora M, Lewandowska I, Marczak $Ł$, Bretes E, Jakubowski H. Cystathionine $\beta$-synthase deficiency: different changes in proteomes of thrombosis-resistant Cbs(-/-) mice and thrombosis-prone CBS(/-) humans. Scientific reports 2020; 10: 10726. [CrossRef]

32. de Rezende MM, D'Almeida V. Central and systemic responses to methionine-induced hyperhomocysteinemia in mice. PloS one 2014; 9: e105704. [CrossRef]

33. Hånell A, Marklund N. Structured evaluation of rodent behavioral tests used in drug discovery research. Frontiers in Behavioral Neuroscience 2014; 8. [CrossRef]

34. Thériault R-K, Perreault ML. Hormonal regulation of circuit function: sex, systems and depression. Biology of sex differences 2019; 10: 12. [CrossRef]

35. Eltokhi A, Kurpiers B, Pitzer C. Behavioral tests assessing neuropsychiatric phenotypes in adolescent mice reveal strain- and sex-specific effects. Scientific Reports 2020; 10: 11263. [CrossRef]

36. Darcet F, Mendez-David I, Tritschler L, Gardier AM, Guilloux J-P, David DJ. Learning and memory impairments in a neuroendocrine mouse model of anxiety/depression. Frontiers in Behavioral Neuroscience 2014; 8. [CrossRef]

37. Beal MF. Aging, energy, and oxidative stress in neurodegenerative diseases. Ann Neurol 1995; 38: 357-66. [CrossRef]

38. Mattson MP. Apoptosis in neurodegenerative disorders. Nature Reviews Molecular Cell Biology 2000; 1: 120-30. [CrossRef]

39. Kowalski K, Mulak A. Brain-Gut-Microbiota Axis in Alzheimer's Disease. Journal of neurogastroenterology and motility 2019; 25 : 4860. [CrossRef]

40. Bulgart HR, Neczypor EW, Wold LE, Mackos AR. Microbial involvement in Alzheimer disease development and progression. Mol Neurodegener 2020; 15: 42. [CrossRef]

41. Saez-Atienzar S, Masliah E. Cellular senescence and Alzheimer disease: the egg and the chicken scenario. Nat Rev Neurosci 2020; 21: 433-44. [CrossRef]

42. Calcinotto A, Kohli J, Zagato E, Pellegrini L, Demaria M, Alimonti A. Cellular Senescence: Aging, Cancer, and Injury. Physiol Rev 2019; 99: 1047-78. [CrossRef]

43. Piechota M, Sunderland P, Wysocka A, Nalberczak M, Sliwinska MA, Radwanska $K$, et al. Is senescence-associated $\beta$-galactosidase a marker of neuronal senescence? Oncotarget 2016; 7: 81099-109. [CrossRef]

44. Muñoz-Espín D, Serrano M. Cellular senescence: from physiology to pathology. Nature Reviews Molecular Cell Biology 2014; 15: 482-96. [CrossRef]

45. Muñoz-Espín D, Cañamero M, Maraver A, Gómez-López G, Contreras J, Murillo-Cuesta S, et al. Programmed Cell Senescence during Mammalian Embryonic Development. Cell 2013; 155: 1104-18. [CrossRef] 